\title{
FEATURES OF INFORMATION COVERAGE IN THE MATERIALS OF INTERNET-MEDIA
}

The issue of the coverage of journalistic materials in online-publications is very important and relevant today. It cannot be said that modern journalists are not trying to control the writing of their articles at all. There are many professional journalists who really put their soul into the work, considering the ethical standards and writing by modern methods of writing and preparing materials, according to the type of specific of the media. However, in order to improve the work of journalists, modern journalism needs to learn the exact knowledge and application of ways to monitor the content of various types of media.

Important skills that a modern journalist should possess are, first and foremost, literary ability, language and style of the author, the ability to express their thoughts and reveal the position of another, the ability to accurately and vividly tell about the event, to convey the fact, evaluate and explain it. His professional competence is also determined by the level of social responsibility to society and the audience, the sense of social justice and the level of his objectivity. It is important that the information which is provided - is true, so that the virtual reality picture adequately reflects the reality.

The purpose of this article is to explore contemporary ways and methods of presenting articles and journalistic materials, depending on the type of media in which journalists submit their material.

Key words: methods of writing of journalistic materials; online-publications; journalist on the Internet; features of the preparation of the article.

Юліана Казімова

\section{ОСОБЛИВОСТІ ВИСВІТЛЕННЯ МАТЕРІАЛІВ У ІНТЕРНЕТ-ВИДАННЯХ}

Досліджено особливості висвітлення журналістських матеріалів у інтернет-3МІ. Це питання актуальне сьогодні, адже журналістів очолюють люди різних рівнів, від чого і залежить спосіб подання інформації у ЗМІ. Також іноді трапляються випадки, коли журналісти онлайн-3МІ подають інформацію не у форматі інтернет-видання, публікують занадто довгі або надто короткі матеріали.

3 метою покращення подання журналістських онлайн-матеріалів застосовано метод моніторингу матеріалів на прикладі інтернет-3МI “Гал-Інфо” та “ZAXID.NET".

Необхідно зазначити, що в інтернет-виданнях посднуються ознаки усіх видів 3МI. Користувачі інтернету мають можливість одночасно отримувати аудіовізуальну та текстову інформацію без використання традиційних ЗМІ. Також інтернет надає інформації такі властивості, як гіпертекстовість, коли читач може отримати найповнішу інформацію про те, що його цікавить, а також інтерактивність, яка дає спожи- 
вачеві змогу вступити у діалог із медіа. Мета статті - дослідити особливості подання журналістських матеріалів у інтернет-виданнях.

Ключові слова: особливості інтернет-матеріалів; сучасний інтернет-журналіст; додаткові властивості публікацій в інтернеті; моніторинг онлайн-публікацій.

Formulation of the problem. Today, the question of the effectiveness of contemporary journalism is quite important. Although this topic in fact is always relevant, it still remains as journalism evolves, and the methods of writing of journalistic material can change. That is why it is important not only to notice these changes, but also to be able to put them into practice. In particular, the issue of preparation of materials for journalists of Internet publications is interesting and relevant today.

The issue of determining - how to submit and prepare material in Internet-media is very important today, because journalists often make certain mistakes, when they are preparing material, which reveals, first of all, their lack of awareness of the specifics of articles in various types of media.

Some of the mistakes that can be found while journalist is working with his article are, for example, submission of the material that essentially meets the requirements of the genre of the article, but for some reason it is placed under a different heading on the site of the publication (as a genre of journalistic message). In order to avoid such and other types of errors, it is necessary to clearly distinguish between the genres of journalism and the specifics of their presentation, appropriate to a particular type of the media.

The purpose of the article is to analyze modern journalism, to determine the current method of preparation of journalistic materials in Internet - media. For this purpose the following tasks were performed: 1) changes in the method of writing journalistic materials were identified; 2) the essence of high-quality contemporary journalism has been clarified; 3) materials of modern mass media are analyzed.

The research methods used in the article include: monitoring, synthesis, comparison, descriptive, and content analysis.

The novelty of the work is the modern assessment of the preparation of journalistic materials on the basis of an analysis of articles on the website of the Internet-media "Gal-Info" and "ZAXID.NET".

The research found that modern journalists are keeping a balance in presenting information, using modern methods of writing materials, taking the initiative to create new methods to engage their audience, trying not to violate the principles of morality, which can be seen on the site "Gal-Info" and "ZAXID.NET".

However, while modern journalists are still trying to adhere to all the principles of reporting, the ability and desire to monitor the work of their colleagues in order to improve their professional activity remains important.

Presenting the main material. Before starting to analyze the state of the art of online journalism, we must first mention its essence, which is that it is a type of creative activity of the person, where the most important is the objective coverage of any side of reality. And in order for modern journalism to meet the relevant requirements, it is necessary that only real professional journalists work in this field [2, p. 287].

It is no secret that today journalistic positions are headed by people of different levels. However, despite this sad fact, it is important to keep in mind that it is essential for the media worker to be able to work quickly and promptly, to be able to adapt and adapt to any circumstances, to work at any time, anywhere.

Important skills that a modern journalist should possess are, first and foremost, literary ability, language and style of the author, the ability to express their thoughts and reveal the position of another, the ability to accurately and vividly tell about the event, to convey the fact, evaluate and explain it [1, p. 383]. His professional competence is also determined by the level of social responsibility to society and the audience, the sense of social justice and the level of his objectivity. It is important that the information which is provided is true so that the virtual reality picture adequately reflects the reality [3, p. 321-324].

It should also be noted that in recent times adherence to norms of ethics is considered as the main component for a journalist, as a particular component of his skill. Given the ability of a person to 
journalism can not be judged without regard to its ethical qualities, which are no less important than qualification [4, p. 324]. Each journalist, in turn, must adhere to the Journalist's Code of Ethics.

It cannot be said that contemporary journalists are not trying to control the writing of their articles at all. There are many professional journalists who really put their soul into the work considering ethical standards. However, in order to improve the work of journalists, modern journalism needs to learn the knowledge and application of the methodology of monitoring the content of various media. This is necessary in order to gain some experience by analyzing the materials of their colleagues, as well as to notice and correct their mistakes.

The essence of the media monitoring method is, first of all, by reading, for example, information from an Internet-media, - see the violation of journalistic standards [5, p. 385]. Monitoring is carried out to evaluate the amount of material in violation of journalistic standards, as well as the time dynamics of changing the quantitative indicators of such violations.

Among the journalistic standards that are primarily addressed in monitoring are the following:

- balance (highlighting the main points of view);

- prompt submission of information;

- reliability of information;

- separation of facts from comments;

- accuracy of information;

- completeness of presentation of facts (information).

For the monitoring of the most up-to-date materials of today's journalists, we take, for example, "Gal-Info" - an online information and analytics agency and "ZAXID.NET" - an analytical online-media.

Among all topical issues that are of concern to society today, Gal-Info reporters most prefer the following: "Tenders for" their own", or how in Lviv they "take care "of the firm of the Association of Persons with Disabilities", "Natural gas consumption has decreased by almost $20 \%$ ", and among the headings: "Economy", "Politics", "Society", "Culture", "Health", "Sport", "Crime", "Emergency", "History", "Treasures of Ukraine", "Lviv", "Ukraine", "News" and more.

In the January 2020 article about the firm of the Association of Disabled Persons, the journalists of "Gal-Info" write about the collective enterprise Center of the Lviv Regional Association of Persons with Disabilities, who is a defendant in criminal proceedings and who is suspected of misappropriation of funds during the repair and reconstruction of a number of buildings and buildings in Lviv, Lviv region.

Journalists managed to find out that according to information in the registers, the ultimate beneficial owners (controllers) of KP Center Complex are currently Pogorilyak Yuriy Ivanovych and Tarasenko Leonid Avramovych, although they are already deceased former heads of the Lviv Regional Association.

According to YouControl, according to the YouControl analytical system, the collective enterprise Center Complex of the Lviv Regional Association of Disabled Persons of the All-Ukrainian Organization of Disabled Persons was registered on July 14, 1993. The head of KP Center Complex is Olexander Khoroshchak.

According to information available in the Unified State Register of Judgments, officers of KP "Center Complex" of LOA IVOI "SOI of Ukraine" appear in the criminal proceeding of July 2, 2016, which is being investigated by the investigative department of the National Police in Lviv region. The proceedings are open at h. 2, 3 Article.191 of the Criminal Code of Ukraine and concerns the squandering/appropriation of another's property by abuse of office and by prior conspiracy by a group of persons.

As we can see, journalists present the material about the firm of the Association of Persons with Disabilities, guided by the facts, and also state that the company of the Association of Persons with Disabilities is a defendant in criminal proceedings.

The article is written clearly, with specific facts and in-depth analysis, and ends with the journalist's note that the issue will be explored in more detail and will be reported further. In this article, Gal-Info submits one small themed photo.

In an article entitled "Natural Gas Consumption Reduced by Almost $20 \%$ ", Gal-Info report that in 2019 relative to 2018 natural gas consumption decreased by $18.2 \%$, and coal by $12.4 \%$, motor gasoline - 
by $8.4 \%$. At the same time, propane and butane use increased by $11.4 \%$, gasoil by $6.6 \%$. And as of January 1, 2020, the enterprises and institutions of the region accounted for 143.3 thousand tonnes of coal; 54.6 thousand tonnes of crude oil, including gas condensate; 11.0 thousand tons of gas oil; 7.8 thousand tonnes of motor gasoline; 2.8 thousand tons of heavy fuel oil; 0.6 thousand tonnes of propane and butane liquefied. In this article, journalists reported changes in gas consumption, comparing its consumption to previous years.

Journalists of this Internet media have chosen interesting columns for coverage of the information, their materials are exemplary, because they comply with the requirements of the journalist's ethics and the requirements for writing professional journalistic materials. For example, under the heading "Lviv", journalists submitted an article in January 2020 entitled "Lviv took first place in the category" Best place for business outsourcing "in Central and Eastern Europe".

The reporters provided a rather interesting piece of material, noting that, following the results of the 8th Annual CEE Business Services Summit \& Awards, Lviv was recognized as the Best City for Business Outsourcing in Central and Eastern Europe by the category of developing cities. The material emphasizes that this is indeed a great achievement for the city of Lviv, as the city has won in the nominations of developing cities, which shows good prospects for potential investors in the city of Lviv. The article states that there are about 120,000 students in Lviv, a great geographical location, the city's infrastructural development, a large number of higher education institutions and training programs, as well as the success stories of existing companies in the field of business process outsourcing. The journalists also commented on the event by Roman Staretskyi, Head of Investment and Projects Department: “... We have to work hard to give this victory a qualitative impetus to the city's development in this direction".

The journalists added that Lviv's competitors were the Hungarian city of Debrecen, the Lithuanian cities of Klaipeda and Kaunas, as well as the Slovakian town of Kosice. This year, more than 320 top executives from 23 countries, as well as more than 75 international firms from Western Europe, Scandinavia, the United States, the United Kingdom and India, have participated in the event.

Unlike "Gal-Info", "ZAXID.NET" journalists favor the following topics in their main posts: "Goncharuk's Films", "What changed on January 1, 2020?", "Medical Reform. Step Two", and among the headings of the Internet-media:"Lviv", "Society", "Economy", "World", "IQ", "Sport", "Photo", etc.

In an article titled "Goncharuk Films", "ZAXID.NET" journalists report that on January 15, 2020, audio recordings made at a meeting with the Prime Minister of Ukraine, where allegedly Oleksiy Goncharuk afforded ambiguous statements on the network the address of the Head of State, Volodymyr Zelenskyi. Publication of the record has provoked considerable resonance among the media and parliamentarians.

Journalists reported that the audio tapes recorded during the Prime Minister's meeting with some ministers and officials were published on an anonymous Youtube channel. "History as Oleksiy Honcharuk, Oksana Markarova (Minister of Finance), Yakiv Smoliy (NBU Chairman), Kateryna Rozhkova (Deputy Head of NBU), Yulia Kovaliv (Deputy Head of President's Office), Dmytro Sologub (Deputy Chairman of NBU) and Tymofiy Mylovanov ) were going to a meeting of Zelenskyi", - says the video description..

Journalists noted that the meeting participants spoke russian. A voice similar to Goncharuk's voice asks to help him explain to the president at a planned economic policy meeting that is taking place with the course, due to which it is strengthened whether there is a hole in the budget of 50 billion UAH and the reasons for the slowdown in economic growth in Q4 2019.

In particular, Goncharuk says about Zelenskyi as a person who is not proficient in economic processes. Subsequently, journalists added that the Cabinet Chairman himself reacted to the information disseminated in the media in an original way: he recorded a video address to "those who are fighting against us". He posted the video on his Facebook page. At the same time, Goncharuk did not say whether the published videos were true. According to him, mass attacks on social networks and mass media have recently been launched against the government and him. In his opinion, this indicates that his team is on the right way. 
The article is titled "What changed on January 1, 2020?" the journalists provided a wealth of useful information at the same time. From January 1, 2020, a number of changes are expected for Ukrainians, in particular, an increase in the minimum wage and the minimum retirement age. Also, with the advent of the new year, the subsistence minimum will increase by UAH 162, which will amount to UAH 2027, and taxes for individual entrepreneurs will increase. Journalists also say that utility monetization will be monetized, as from January 1, 2020, Ukrainians will receive privileges and subsidies for housing and communal services, purchase of solid and liquid stove fuel and liquefied gas only with money. At the same time, preferential categories of Ukrainians will be able to apply at any time to switch to cash payments for housing and communal services. Reporters also noted that the government had earlier abolished a restriction that did not allow Ukrainians to apply for monetization after October 15. The price of gas and its payment were also submitted: "On January 1, 2020, there will be changes in the gas market - Ukrainians will be able to choose a gas supplier on favorable terms for themselves. Payment for gas will be made under two schemes: either at the guaranteed price, which will be valid until the end of the quarter, or at the market price. In addition, the material is titled "What changed on January 1, 2020?" journalists reported that from January 1, 2020, fines for foreign owners of cars with foreign registration will end in the country. Then law enforcement officers get a formal right to fine the owners of drivers of such vehicles and to pay them fines in the amount of 170 thousand UAH. Also, from January 1, the law on electric vehicles will come into force in Ukraine. In particular, from the beginning of the year, drivers of gasoline and diesel cars at the legislative level will be prohibited from parking on the ground for electric vehicles.

The article is titled "Medical Reform. Step Two" "ZAXID.NET" journalists report that, from April 1, 2020, significant changes are awaiting healthcare facilities that provide specialized (city, district hospitals) and highly specialized (regional hospitals and centers) medical care. The program of medical guarantees (which determines the list and volume of medical services and medicines that the state will pay for the state budget money for patients) also provides pleasant surprises for patients, practically all medical care is promised to provide them for free. One of the most important changes in medical reform is that from April 1, we will no longer officially have medical facilities, it will be unprofitable to be a mediocre hospital or a mediocre specialist because there will be no fixed salary, and the patient will have the right to choose either a consultation or a planned operation, will go to the specialist he chooses, whom he thinks is the best. There are also increased requirements for hospitals that want to provide care for stroke, heart attack (these are priority services). They should be provided with the right equipment to help make an accurate diagnosis: computed tomography, magnetic resonance imaging, angiography.

Patients will be free to choose narrow specialists who want to consult or undergo surgery, following the example of how they have chosen a family doctor. They can also freely choose the hospital where they plan to repair their health - they will no longer be able to bind to the area or city, and will only receive free advice or assistance with the guidance of their family doctor. Referral to narrow specialists will be electronic, as will the patient's medical card. All medical care for heart attack or stroke for the patient will be free, namely: angiography, emergency laboratory tests, thrombolytic therapy for stroke, stenting for heart attack, as well as round-the-clock monitoring of the patient in reanimation, rehabilitation.

Conclusions. So, "ZAXID.NET" journalists like Gal-Info prefer similar topics, but the method of writing articles is different. After all, if Gal-Info journalists provide law-related information or important information through facts, explanations and details, and prefer a smaller volume of articles on such topics, then "ZAXID.NET" journalists submit more detailed material. However, both "Gal-Info" and "ZAXID.NET" journalists adhere to moral principles, balance of information and material writing principles, as well as use modern method of article creation. "Gal-Info" journalists provide important information about the Association of Persons with Disabilities and the consumption of natural gas, and in their materials there are good photo illustrations. And "ZAXID.NET" journalists report on changes in medical reform, changes since January 1, 2020, and among their headlines are interesting ones called "IQ" and "Photos". There are no such headings in Gal-Info, but there are more headings on the "Gal-Info" site than in "ZAXID.NET". It can be concluded that both "Gal-Info" and "ZAXID.NET" journalists professionally prepare their materials and qualitatively select topics for coverage, after all, as many 
columns as in "Gal-Info", which provide a more comprehensive coverage of important topics for the audience, as well as a compact number of columns that are interconnected and interesting, as in "ZAXID.NET", - these two methods of the presentation of materials are good, both one and the other. But in essence, the approach to creating a balance in the presentation of information in both "Gal-Info" and "ZAXID.NET" is at a high, professional level.

\section{References}

1. Kalmykov A. A. Internet journalism: textbook. manual for university students studying in special. 021400 “Journalism” / A. A. Kalmykov, L. A. Kohanova. M.: UNITI-DANA, 2005. 383 p.

2. Korkonosenko S. G. Fundamentals of Journalism: A Textbook for Universities / S. G. Korkonosenko. M.: Aspect Press, 2001. 287 p.

3. Kotsarev O. O. Typology of Internet-media // Scientific notes of the Taurida National University. V.I. Vernadsky. Avg. Philology. 2006. T. 19. No. 5. P. 321-324.

4. Craig R. Internet journalism: the work of a journalist and editor in the new media / Richard Craig; trans. from English. A. Ishchenko. K.: Kind of. House of Kyivo-Mohylians'ka Academy, 2007. $324 p$.

5. Meleshchenko O. K. Internet technologies in modern journalism: models and practice: textbook. tool / O. K. Meleshchenko. K.: KimU, 2005. 385 p. 